Ethiopian Journal of Environmental Studies \& Management 9(Suppl. 1): 804 - 814, 2016.

ISSN: 1998-0507

doi: http://dx.doi.org/10.4314/ejesm.v9i1.1S

Submitted: February 05, 2015

Accepted: November 17, 2016

\title{
ASSESSMENT OF PRECAUTIONARY MEASURES IN AGROCHEMICALS USAGE AMONG URBAN ARABLE CROP FARMERS IN OYO STATE, NIGERIA
}

\author{
OJO, T.F., ${ }^{1}$ KOLEDOYE, G.F. ${ }^{2}$ AND OLANIRAN, F.I. ${ }^{1}$ \\ ${ }^{1}$ Department of Agricultural Extension and Rural Development, Obafemi Awolowo \\ University, Ile Ife, Nigeria \\ ${ }^{2}$ Department of Agricultural Extension and Rural Development, Adekunle Ajasin \\ University, Akungba Akoko, Ondo State, Nigeria
}

\begin{abstract}
The paper identified the various agrochemicals used by urban farmers and analysed their level of precautionary measures taken to avert hazards associated with the use of the identified agrochemicals. A sample of 120 urban farmers were used for the study. The findings revealed that majority (86.7\%) of the respondents were married with relatively high household size. The average annual income from their farming activities was \#347,649.38. The common agrochemicals used by the farmers with their trade names were paraquat, diazinion, weed-off, round-up and premextra.. It was observed that that frequency of use of herbicides ( $b=-0.249)$ and fungicides $(b=0.361)$ had significant relationship with the level of precautionary measures observed by the farmers. Correlation analysis revealed that level of precautionary measures observed by farmers had a positive relationship with the perceived health effects ( $r=0.209 ; P \leq 0.022)$ of agro-chemicals. It was also revealed that farmers' knowledge of health hazards in relation to agrochemical usages was low. The study recommends rigorous campaign on the hazzards associated with the use of agro-chemicals among urban farmers by extension agents and social workers with a view to reducing the health hazards that may result from improper precautionary measures.
\end{abstract}

Key Words: Precautionary measures, Agrochemicals, Urban farmers, Arable crops

Introduction

Involvement of Nigerians in urban agriculture cannot be understimated. This may be unconnected with the problem of food insecurity that has engulfed the nation for the past two decades owing to her over depended on crude oil as the major source of revenue (Manyong et al., 2005). Urban agriculture which involves the cultivation, processing, and distribution food in or around a town, or city (Yassin et al., 2002) has been used as one of the strategies to reduce the incidence of food scarcity and discourage food importation from neighouring countries in Nigeria. It also involves animal husbandry, aquaculture, agroforestry and horticulture (Naido et al., 
2010). This type of agriculture is usually practiced on a small and medium scale level. Adeola (2012) described urban agriculture as type of agriculture generally practiced for income-earning as well as household food-production especially, among lower income earners. Although, in some communities it is mainly done for recreation and relaxation (Salau and Attah, 2012). In the view of Yassin et al. (2002) urban agriculture involves the cultivation of crops and rearing of animals for human or household consumption and commercial purposes within the urban centres. It takes place on private, leased or rented land in peri-urban areas, in backyards, on roof tops, on vacant public lands such as industrial parks, school grounds, roadsides and other institutions as well as ponds, lakes, and rivers (Damas et al., 2006).

According to the 2002 American Community Survey, the population of the United States is 280,540,303 (US Census). Over 80 percent of this figure live in metropolitan areas, thus, urban agriculture accounts for about 78 percent of the total food consumed in such region (Community Food Security Coalition CFSC, 2003). In Nigeria, the case is different as over 75 percent of the food consumed in urban areas are produced in rural areas (Okolo, 2006). UNDP report (2003) revealed the population of farmers practising urban farming across some selected African countries. The report showed that about 35 percent in Yaoundé (Cameroon), 36 percent in Ouagadougou (Burkina Faso), 37 percent in Maputo (Mozambique), 45 percent in Lusaka (Zambia), 68 percent of urban dwellers in six Tanzanian cities, 80 percent of families in Libreville (Congo) and less than 25 percent in Nigeria are involved in urban agriculture.

Interestingly, the importance of urban agariculture cannot be overlooked especially in fighting the menace of food insecurity in developing countries (Ishaya et al., 2007). It plays an important role as part of an environmental sustainability program. Physically, it increases green space, which reduces the urban heat generated as a result of the industrial activities, stops water run-off, and improves air quality. Urban agriculture also reduces energy consumption and pollution associated with transportation. It provides social benefits by providing inexpensive access to locally-grown produce. The increasing population growth of recent years has brought the issue of sustainability to the forefront. Urban agriculture is one way to significantly impact not only people's lives, but also environmental sustainability. Furthermore, urban agriculture is potentially a source of income i.e. lucrative (Chickoye et al., 2007). Urban agriculture contributes to food security and food safety in two ways: first, it increases the amount of food available to people living in cities, and second, it allows fresh vegetables, fruits, and meat products to be made available to urban consumers.

Urban agriculture is commonly regarded by some people as an activity that is marginal, temporary and old. Some also perceived it as a practice that is harmful to farmers' health, consumers' health and our environment due to the use of agrochemicals. The use of pesticides in urban agriculture has been identified to have adverse health effects such as impotency and infertility on farmers in Ghana (Mancini et al., 2005). 
Despite the importance of urban agriculture as a key factor in sustainable food security to urban population. Some of the practices carried out by farmers have been discovered to pose some health risks and the farmers are thereby susceptible to occupational and other health related problems from the use of agrochemicals. For instance, the exposure of farmers without protective wears to pesticides which have long-term health problems such as dizziness and memory disorders, impotency in men and infertility in women. Naido et al. (2010) identified schistosomiasis, cholera, bacterial diseases, nematode infections, malaria, headaches, dermatological, visual, cardiac and respiratory problems as the health problems associated with the use of agrochemicals in Ghana. Ogunjimi and Farinde (2012) identified redness of eyes, cough, difficulty in breathing, excessive sweating, headache, baby itching, lack of muscle coordination and yellowing of skin were associated with the use of agrochemicals in Edo State. In addition, Ajayi and Akinnifesi (2008) identified respiratory infections, dematosis, allergies, cancer as the major diseases occurring in agricultural works. World Health Organisation estimated that over 3 million farmers in the developing countries experience severe poisoning from pesticide exposure where about 18,000 , representing 6.0 percent die annually due to the inappropriate precautionary measures. This situation, therefore, calls for a careful study of the precautionary measures among urban farmers in the use of agrochemicals in Oyo State, Nigeria. Specifically, the study described the socio-economic and personal characteristics of the farmers involved in urban agriculture, identified the types of agrochemicals used and sources and determined the level of precautionary measures taken by farmers using agrochemicals in the study areas

\section{Materials and Methods Study Area}

The study was carried out in Oyo State, Nigeria. The state covers an area of approximately 28,454 square kilometers with a population of 5,591,589 according to 2006 National Population Census figure. It is ranked 14th by size and the state is made up of Thirty Three (33) Local Government areas. Oyo State is located between latitude $7^{\circ}$ and $9^{\circ}$ North of the Equator and longitude $2^{\circ}$ and $4^{\circ}$ East of the Greenwich Meridian. The State is broadly occupied by Yoruba speaking people. The major occupation of the people is farming, which employs over 60 percent of the entire population. The climate is equatorial, notably with dry and wet seasons with relatively high humidity. Average daily temperature ranges between $25^{\circ} \mathrm{C}$ and $35^{\circ} \mathrm{C}$ almost throughout the year round. The climate in the state favours the cultivation of both arable and tree crops.

\section{Sampling Technique and Sample Size}

Multi-stage sampling technique was used to select the sample for the study. About 50 percent of the four Agricultural Development Programme (ADP) zones (Ibadan and Ogbomoso) were purposively selected based on their degree of food production in the State. At the second stage, 3 communities were randomly selected from each of the ADP zones based on their high level of urbanisation, making a total of six communities. At the third stage, 20 urban farmers were randomly selected in each of the six communities. A total of 120 
farmers were with the use of questionnaire and interview schedule. Data collected were described with frequency counts, percentages, mean and charts while correlation and regression analyses were used to make inferences from the data.

\section{Results and Discussion Socio-economic Characteristics}

Results in Table 1 showed that 7.5 percent of the respondents were less than 30 years of age, 81.7 percent were between ages of 30 and 59 years while 10.8 percent had their ages ranging between 60 years and above. This implies that majority of the respondents were between the ages of 30-59years. The mean age was found to be $44.05 \pm 10.76$ years. This implies that the farmers were still active and as such they will still be able to withstand the tedious nature of farming. The finding coincides with the findings of Adeogun and Agbongiarhuoyi (2009); Babatunde et al. (2007) which asserts that the mean of farmers in Nigeria is 46.5 years. The findings also showed that only 10.0 percent of the respondents are reported to be single, 86.7 percent married, while 1.5 percent of the respondents were divorced. This result corroborates the earlier report of Okolo (2006) which stated that the highest numbers of people that are engaged in rural farming in Nigeria are married. In addition, about 79.2 per cent of respondents were male and 20.8 per cent were female. The findings revealed that majority $(79.2 \%)$ of the respondents were male. This implies that there were more male farmers in the study areas that female. These results agree with the findings of Oguntola (1998) who concluded that farming is a maledominated profession. The mean household size was $5.68 \pm 1.76$ persons per household. This implies that farmers in the study area had relatively high household size compared to the United Nations household standard of 4 persons per household. Results in Table 1 further showed that only 3.3 percent of the respondents attended primary school education, 63.3 percent had secondary education while 33.3 percent of them passed through various tertiary institutions. This implies that majority $(63.3 \%)$ of the farmers in the study area had a minimum of secondary education. This corroborates with the findings of Olowogbon et al. (2013) that majority of the farmers in Oyo state are literates. However, the findings contradicts the report of Oladele (2001) that over $60 \%$ of livestock farmers in Oyo State had no formal education. The mean years of farming experience was 15.02 \pm 11.37 years. This implies that respondents's farming experience was relatively low compared to the findings of Ogunjimi and Farinde (2012) and Tijani and Sofoluwe (2012) who reported that farmers in Edo and Ondo States of Nigeria had above 20 years of farming experience. Farmers make on average $\$ 347,649.38 \pm \$ 132,689.35$ per season from farming.

Results in Figure 1 showed that 57.5 per cent of the respondents were Christians while 42.5 per cent were Muslims. The results revealed that Christianity and Islam are the major religions practiced in the study area. 
Table 1: Distribution of respondents selected socio-economic characteristics

\begin{tabular}{lllll}
\hline Variable & Frequency & Percentage & Mean & Std.Dev \\
\hline Age & & & & \\
$<30$ years & 9 & 7.5 & & 10.76 \\
$30-60$ years & 98 & 81.7 & 44.05 & \\
60 years and above & 13 & 10.8 & & \\
Marital status & & & & \\
Single & 12 & 10.0 & & \\
Married & 104 & 86.7 & & \\
Divorced & 4 & 3.3 & & \\
Sex & & & & \\
Male & 95 & 97.2 & & \\
Femal & 25 & 20.8 & & \\
Household size & & & & \\
$<4$ & 8 & 6.7 & & \\
4-7 & 95 & 79.2 & 5.68 & \\
8 and above & 17 & 14.2 & & 11.37 \\
Formal Education & & & & \\
Primary & 4 & 3.3 & & \\
Secondary & 76 & 63.3 & 11.23 & \\
Tertiary & 40 & 33.3 & & \\
Farming experience & & & 15.02 & \\
Annual income & & & & \\
\hline
\end{tabular}

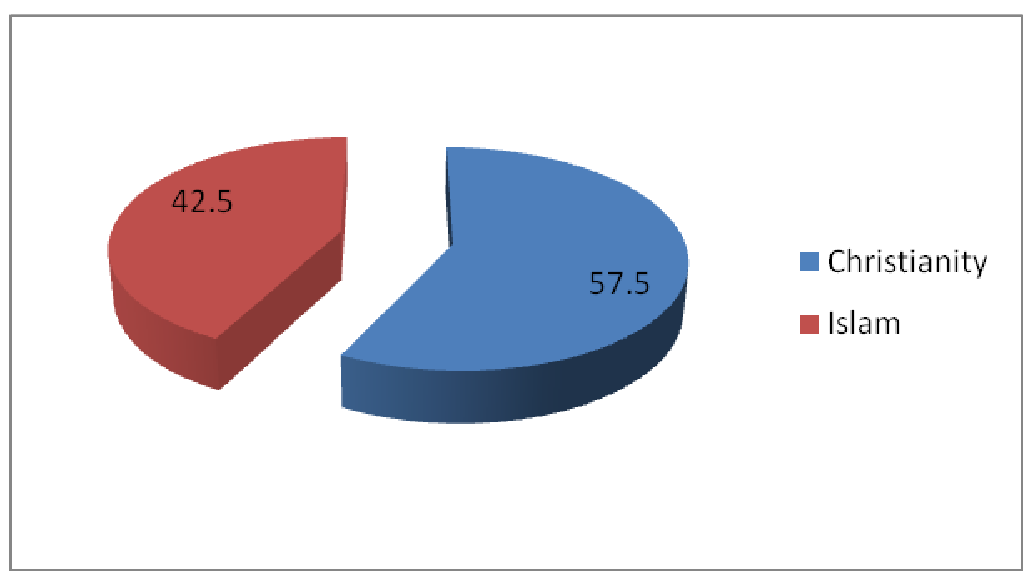

Figure 1: Distribution of respondents by religion

\section{Types of Agrochemical Used}

Results in Table 2 showed that 70.8 percent of the farmers used Primextra, 37.5 percent used rodeo, 84.2 percent used Weed-off and 59.2 percent used force-up while about 85.0 percent used Paraquat. In addition, 60.0 percent of the respondents used Round-up, 77.5 percent used Glyphosate, 55.8 percent used Sorosate, 20.0 percent used touch-down, 35.0 percent used Lindane while only 6.7 percent of them used Endosulfan. Furthermore, 26.7 percent of the respondents used Dursban, 48.3 percent 
used Actara, 7.5 percent used Malathion, 13.3 percent used Diazinion, 85.0 used Gammalin 20 and about 15.8 percent used Ridomil gold 66WP. Moreso, 25.8 of the farmers used Funguran, 20.0 percent used Nordox, 10.8 percent Kocidel 101, 22.5 percent used Manzate, 9.2 percent used Diathane, while only 1.7 percent of them used thiolux. The implications of this findings was that majority of the respondents in the study area used Primextra, Weed off, Force up, Paraquat, Round up, Glyphosate, Sorosate and Gammalin 20 and markets and Non-Governmental organisations were the major sources of these agrochemicals to the farmers. The findings revealed that Gammalin 20 (85.0\%), Paraquat $(85.0 \%)$, Weed off (84.2\%), glyphosate $(77.5 \%)$, Primextra $(70.8 \%)$ and Round-up (60.0\%) were the major agro-chemicals used in the study area. The findings corroborate Ogunjimi and Farinde (2012) and Adeola (2012) assertions that most farmers in Edo and Southwestern states in Nigeria used Gammalin -20 and Primextra as the major agrochemicals in their farming operations.

Table 2: Types of agro-chemicals used and sources

\begin{tabular}{llll} 
**Types of agro-chemicals used & Frequency & Percentage & Sources \\
Herbicides & & & \\
Primextra & 85 & 70.8 & Mkt, NGO \\
Rodeo & 45 & 37.5 & Mkt, NGO \\
Weed off & 101 & 84.2 & Gvt, Mkt, NGO \\
Force up & 71 & 59.2 & Gvt, Mkt, NGO \\
Paraquat & 102 & 85.0 & Gvt, Mkt, NGO \\
Round up & 72 & 60.0 & Mkt, NGO \\
Glyphosate & 93 & 77.5 & Mkt, NGO \\
Sorosate & 67 & 55.8 & Mkt, NGO \\
Touch down & 24 & 20.0 & Gvt, Mkt, NGO \\
Insecticides & & & \\
Lindane & 42 & 35.0 & Mkt, NGO \\
Endosulfan & 8 & 6.7 & Gvt, Mkt \\
Dursban & 32 & 26.7 & Mkt, NGO \\
Actara & 58 & 48.3 & Gvt, Mkt, NGO \\
Malathion & 9 & 7.5 & Gvt, Mkt, NGO \\
Diazinion & 16 & 13.3 & Mkt, NGO \\
Gammalin 20 & 102 & 85.0 & Mkt, NGO \\
Fungicides & & & \\
Ridomil gold 66WP & 19 & 15.8 & Gvt, Mkt, NGO \\
Funguran & 31 & 25.8 & Gvt, Mkt, NGO \\
Nordox & 24 & 20.0 & Mkt, NGO \\
Kocidel 101 & 13 & 10.8 & Mkt, NGO \\
Manzate & 27 & 22.5 & Gvt, Mkt, NGO \\
Diathane & 11 & 9.2 & Mkt, NGO \\
Thiolux & 2 & 1.7 & Mkt, NGO \\
\hline
\end{tabular}

** Multiple responses.

Govt $=$ government, $\mathrm{Mkt}=$ market $. \mathrm{NGO}=$ non-governmental organisation 
Level of Precautionary Measures Among Farmers in the Use of Agrochemicals

Results in Table 3 showed that overall/outer garments $(\bar{X}=2.92=3.4)$, hand gloves $(\bar{X}=2.92=3.3)$ and the use of boot $(\bar{X}=3.1)$ while spraying agrochemicals were occasionally used while respirator/nose cover $(\overline{\mathrm{X}}=2.92=2.0)$ was rarely used. However, eye protection lens and other means of taking precautions were never used. The grandmean score of 3.0 used as a benchmark indicates that farmers only takes high level of precautionary measures in the use agro-chemicals by using overall/outer garments, hand gloves and boots. The inability of the farmers to use the full precautionary measures that include nose and eyes protectors may be due to the fact that they do not have adequate knowledge of the health problems that could be contacted by inhaling the chemicals. The findings show that farmers do not take full precuationary mesures as respirator/nose covering and eye protection lens are not wore. This may be hazardous to their health if adequate measures are not taking while using agro-chemicals as it is be very easy to inhale the dangerous active ingredients in these agrochemicals by the farmers. This means that farmers in the study area were not using full precautionary measures as expected. This corroborates the findings of Oluwafemi and Robert (2009) report that majority of farmers in Ekiti State never used any form of protective equipment except their normal clothes with only $11.1 \%$ using boots as protective measures against agro-chemicals. Also, the result agreed with Muhammad (2009) who claimed that very few farmers took precautionary measures during the application of agrochemicals in Pakistan.

Table 3: Level of Precautionary Measures among Urban Farmers Using Agro-chemicals

\begin{tabular}{|c|c|c|c|c|c|c|}
\hline Variable & Not at all (1) & Rarely (2) & Occasionally (3) & Regular (4) & Very regular (5) & Mean \\
\hline Respirator/nose cove & $16(13.3)$ & $9(7.5)$ & $28(23.3)$ & $46(38.3)$ & $21(17.5)$ & 2.0 \\
\hline Boot & $11(9.2)$ & $17(14.2)$ & $20(16.7)$ & $49(40.8)$ & $23(19.2)$ & $3.1 *$ \\
\hline $\begin{array}{l}\text { Overalls/outer } \\
\text { garments }\end{array}$ & $10(8.3)$ & $8(6.7)$ & $31(25.8)$ & $39(32.5)$ & $32(26.7)$ & $3.4^{*}$ \\
\hline Eye protection lens & $52(43.3)$ & $20(16.7$ & $28(23.3)$ & $16(13.3)$ & $4(3.3)$ & 0.8 \\
\hline Hand gloves & $21(17.5)$ & $7(5.8)$ & $11(9.2)$ & $53(44.2)$ & $28(23.3)$ & $3.3 *$ \\
\hline Others & $118(98.3)$ & $1(0.8)$ & $1(0.8)$ & 0 & 0 & 0.2 \\
\hline
\end{tabular}

Figures in parentheses represent percentage.

Grandmean score $=3.0$

$* X \geq 3.0=$ High level of precautionary measure observed

An in-depth analysis was conducted to determine level of precautionary measures taken by farmers in using these agrochemicals. 'Mean plus and minus standard deviation was used for this categorization. Results revealed that 31.7 percent of the farmers were rated low in their level of precautionary measures taken, about 51.7 percent had moderate while only 16.7 percent took high level of precaution as presented in Figure 2. The finding revealed that slightly above average (51.7\%) of the farmers moderately practiced the identified precautionary measures. 


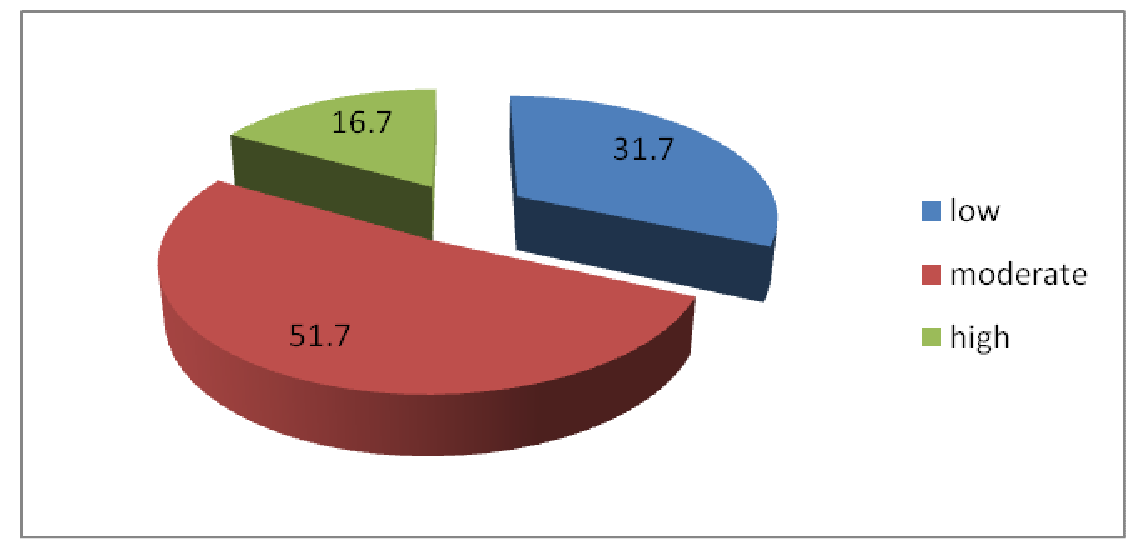

Figure 2: Farmers Level of Precautionary Measures in the Use of Agro-chemicals

Relationship Between Level of Precautionary Measures in the Use of Agro-chemicals and their Frequency of Use

Table 4 shows the results of Pearson Product Moment Correlation showing relationship between frequency of use of agro-chemicals and level of precautionary measures observed by farmers. It was observed that significant relationship exists between frequency of use of fungicides $(\mathrm{r}=-0.401 ; \mathrm{p} \leq 0.01)$ and insecticides $(\mathrm{r}=0.356 ; \mathrm{p} \leq 0.05)$ as well as herbicides $(\mathrm{r}=0.228 ; \mathrm{P} \leq 0.05)$. This shows that frequency of use of fungicides and and insecticides posively correlated with the precautionary measures taking durng their uses. The non-significant relationship of the use of herbicide and precautionary measure observed may not be unconnected with the fact that herbicide is the most commonly used agro-chemical among farmers in the study area. Thus, farmers must have developed several ways of using them with little or not precautionary measures taken. However, fungicides and insecticides which are rarely used may be seen as more dangerous chemicals for the farmers. Hence, they take more precautionary measures in their uses. The findings support the Ishaya et al. (2007); Ogunjimi and Farinde (2012) ; Chikoye et al. (2007) and Dimas et al. (2006) reports that herbicides were the most common agro-chemicals used by farmers in Nigeria and Namibia.

Table 4: Results of Pearson's Product Moment Correlation showing relationship between level of precautionary measures observed by farmers and frequency of use of agrochemicals

\begin{tabular}{llll}
\hline Variable & Correlation Coefficient $(\mathrm{r})$ & P-value & Decision \\
\hline Frequency of use of herbicides & 0.228 & 0.05 & $\mathrm{~S}$ \\
Frequency of fungicides & $0.401^{* *}$ & 0.01 & $\mathrm{~S}$ \\
Frequency of insecticides & $0.356^{*}$ & 0.05 & $\mathrm{~S}$ \\
\hline
\end{tabular}

**Significant at 0.01 level; *Significant at 0.05 level 
Level of Precautionary Measures and Percieved Health Effects Associated with the Use of Agro-chemicals

Results in Table 5 showed that level of precautionary measures observed by farmers had a significant relationship with the perceived health effects $(r=$ $0.209 ; \mathrm{P} \leq 0.022$ ) associated with the use of agro-chemicals in the study area. This implies that farmers take precautionary measures when they perceived any health problem in the use of agro-chemicals among urban farmers in Oyo State due to the fear of having some of the health related issues that can be injurious to the farmers. However, it argues with the findings of Ogunjimi and Farinde (2012) which identified that a non-significant relationship exists between knowledge level of precautionary measures and perceived health problems associated with the use of agro-chemicals among farmers in Edo and Osun States, Nigeria. However, Bhoopendra and Mudit (2009) concluded that farmers in Idia rarely protect themselves during application of agro-chemicals, hence various diseaes such as skin irritation, redness of eyes and other diseases had been identified due to the poor use of protective wears among farmers.

Table 5: Results of correlation analysis showing relationship between level of precautionary measures observed by the farmers and perceived problems associated with the use of agro-chemicals.

\begin{tabular}{llll}
\hline Variable & Correlation coefficient $(\mathrm{r})$ & $\begin{array}{l}\text { Coefficient } \\
\text { determination }\left(\mathrm{r}^{2}\right)\end{array}$ & ofDecision \\
\hline Perceived problem scores & $0.209^{*}$ & 0.0436 & $\mathrm{~S}$ \\
\hline
\end{tabular}

\section{Conclusion}

Agrochemical poisoning is a global health problem, and it is more prevalent in developing countries of the world. The harmful effects of these chemicals on human beings have been established by extant literature and this could be very fatal when adequate precautionary measures are not observed by the userd. The incidence of pesticide poisoning is increasing according to the existing reports, and it is estimated that about 5 million people die every year as a result of intentional, accidental and occupational exposure worldwide to the various agrochemicals. Some of these chemicals find their ways into the streams and water bodies where either directly or indirectly we consume them, hence the need to investigated the level of precautionary measures observed among urban farmers in Oyo State becomes the focus of the study. Based on the findings, majority of the urban farmers in Oyo state were married with relatively high household size. Christianity and Islam were the dominant religion among the farmers. The average annual income from their farming activities was $\$ 347,649.38$. the common agrochemicals used by the farmers were paraquat, diazinion, weed-off, round-up and premextra. The major sources of these agro-chemicals are market and NGOs. The findings revealed that there was a moderate level of precautionary measures observed by the farmers in the use of agrochemicals. Frequencies of use of fungicides and insecticides and health hazards associated with agro-chemical 
usage were the correlates of precautionary measures observed. The study concludes that if these farmers are made to understand the danger involve in the use of agro-chemical without appropriate measures, level of precautionary measures would be high. The study therefore recommends that stakeholders in the Federal Ministry of agriculture in conjuction with the Federal Ministry of health should embark on a compaign that will enlighten the farmers in the various hazzards associated with the use of agro-chemicals with a view to reducing the health related issues associated with the use of agro-chemicals among urban farmers in Nigeria.

\section{Acknowledgement}

We acknowledge the effort of $\mathrm{Mr}$. Adekunle Waheed (Fadama facilitator, Oyo State) for his support during the data collection for this study. Femi Omonijo is appreciated for his assistance for data inputation.

\section{References}

Adeogun, S.O and Agbongiarhuoyi, A.E. (2009). Assessment of Cocoa Farmers Usage Pattern in Pest and Disease Management in Ondo State. J. Innov. Dev. Strategy. 3(2): 27-34.

Adeola, R.G. (2012). Perceptions of Environmental Effects of Pesticides use inVegetable Production by Farmers in Ogbomoso, Nigeria: Global Journal of Science Frontier Research Agriculture and Biology. 12(2): 23-31.

Ajayi, O.C. and Akinnifesi, F.K. ( 2008). Farmers' understanding of pesticide safety labels and field spraying practices: a case study of cotton farmers in northern Cote d'Ivoire. Sci. Res. Essays, 2: 204-210.
Babatunde, R.O., Fakayode, S.B., Olorunsanya, E.O. and Gentry, R.A. (2007). Socio-Economics and saving patterns of cooperative farmers in South-Western Nigeria. Medwell Journal of Social Sciences, 2(3): 287292.

Bhoopendra, S. and Mudit, K.G. (2009). Pattern of use of personal protective equipments and measures during application of pesticides by agricultural workers in a rural area of Ahmednagar district, India. Indian J: of Occup Environ Med., 13(3): 127130.

Chikoye, D., Ellis-Jones, J. Riches, C. and Kanyomeka, L. (2007). Weed management in Africa: experiences, challenges and opportunities, XVI International Plant Congress, pp 6523.

Community Food Security Coalition (CFSC), North American Urban Agriculture Committee. 2003. Urban Agriculture and Community Food Security in the United States: Farming from the City Center to the Urban Fringe. (City): North Americn Urban Agriculture Committee.

Damas, C. A.; Georgiou, E. B.; Theodorou, M .G. (2006). Pesticide use and safety practices among Greek tobacco farmers: A survey. Int. J. Environ. Health Res., 16(2), 339-22 348.

Dimas, S.J., Ogunmokua, A.A. and Nantanga, T. (2002). The status of urban and peri- urban agriculture. A survey report prepared for integrated support to sustainable development and food security programme in Namibia.

Ishaya, D.B., Dadari, S.A. and Shebayan. J.A.Y. (2007). Evaluation of herbicides for weed control in sorghum (Sorghum bicolour) in 
Nigeria, Crop Protection, 26, pp 16971701.

Mancini, F., Van Bruggen, A.H.C., Jiggins, J. L.S., Ambatipudi, A.C. and Murphy, H. (2005). Acute pesticide poisoning among female and male cotton growers in India. Int. J. Occup. Environ. Health, 11: 221-232.

Manyong, V.M., Ikpi, A. Olayemi, J.K., Yusuf, S.A., Omonona, B.T., Okoruwa, V. and Idachaba, F.S. (2005). Agriculture in Nigeria: Identifying opportunities for increased commercialization and investment. Funded by USAID-Nigeria Implemented by International Institute of Tropical Agriculture (IITA) in collaboration with the University of Ibadan. Pg. 13

Muhammad, K (2009). Adverse Health Effects, Risk, Perception and Pesticide Use Behaviour. Federal Ardu University of Arts, Science and Technology, Islamabad, Pakistan.

Naidoo, S.L., London, P.O. and Rother, H.A. (2010). Pesticide safety training and practices in women working in small-scale Agriculture in South Africa. Journal of Occupational Environment Medicine, 67(12): 823828.

Nationa Population Census (2006)

Ogunjimi, S.I. and Farinde, A.J. (2012). Farmers' Knowledge Level of Precautionary Measures in Agrochemicals Usage on Cocoa Production in Osun and Edo States, Nigeria.

Oguntola S.I. (1998). Female-oriented Technologies in Agricultural research Institutes in Oyo state. Unpublished B.Sc thesis in the Department of Agricultural Extension and Rural Development, University of Ibadan, Nigeria.
Okolo, D.A. (2006). Agricultural development and food security in SubSaharan Africa; the case of Nigeria, FAO working paper No. 5 .

Oladele, O.I (2001). Farmer Perception of the Relevance of Livestock Production Technologies in Oyo state, Nigeria: Livestock Research for Rural Development, 13(16): 17-26.

Olowogbon, T.S., Fakayode, S.B., Jolaiya, A.J. and Oke, A.O. (2013). Nigeria's Small Scale Farmers' Agrochemical Use the Health and Safety Implications. Journal of sustainable development in Africa, 15(1): ISSN: 1520-5509.

Oluwafemi .O. and Robert C.A. (2009). Health and environmental impacts of pesticide use practices: a case study of farmers in Ekiti State, Nigeria. International Journal of Agricultural Sustainability, $\quad 7(3): 153-163 . \quad$ ISSN 1473-5903 (Print), 1747-762X (Online)

Salau, E.S. and Attah, A.J. (2012). A SocioEconomic Analysis of Urban Agriculture in Nasarawa State, Nigeria. PAT, 8(1): 17-29.

Tijani, A. and Sofoluwe, N. (2012). Assessment of Farm Level Pesticide Use among Maize Farmers in Oyo State, Nigeria. Food Science and Quality Management ISSN 2224-6088 (Paper) ISSN 2225-0557, Vol. 3.

United Nations Development Programme. (UNDP) (2003). Human Development Report, UNDP, Oxford University Press, New York, 292pp.

Yassin, M.M., Abu-Mourad, T.A. and Safi, J.M. (2002). Knowledge, attitude, practice and toxicity symptoms associated with pesticide use among farm workers in Gaza Strip. Journal of Occupational Environment Medicine,

59:387-394 